\title{
ІНВЕРСІЯ ПРОЦЕСІВ, НАСЛІДКІВ І УСВІДОМЛЕННЯ РЕВОЛЮЦІї
}

На початку XXI ст. темпи соціального розвитку стали настільки стрімкими і драматичними, що гострі питання, поставлені його зламами і змінами, вимагають не лише науково обгрунтованих теоретичних відповідей, а й відповідних політичних дій. В усьому світі мільйони людей $з$ пасивних спостерігачів перетворюються на активних учасників історичних подій, але залучаються вони в суспільні процеси нерівномірно і аж ніяк не 3 доброї волі. За характеристикою Б.Ю.Кагарлицького [6, 6], громадянська дія стає необхідністю та водночас перетворюється на проблему - в Свропі, в країнах Арабського світу. Виявляється, що масова соціально-політична дія розгортається незалежно, всупереч існуючим політичним інститутам. Партії постали ні на що не придатними, парламенти - такими, що не відповідають потребам суспільства, ігнорують його колективну волю (у Франції - не менш відверто, ніж у Сгипті чи Греції або в Росії). Суспільства Близького Сходу після тривалого мовчання піднесли свій голос, тоді як Східна Європа розривалася між примарами минулого і вимогами майбутнього.

Події «Арабської весни» продемонстрували як теоретичну слабкість, так і практичну неготовність, політичну недієздатність багатьох традиційних громадських рухів та політичних організацій. Активістам в арабських країнах доводилось вчитися на ходу, тоді як, скажімо, в Сполучених Штатах виникала унікальна короткочасна можливість розібратися в процесах, що відбувалися, розгледіти певну тенденцію раніше, ніж хвиля змін захопила країну.

Поняття «революція» визначається в контексті полеміки, теоретичної дискусії, що спричинені багатогранністю і різноманітністю змісту цього поняття. Найпоширенішими є дослідження поняття «революція» в соціальному і філософсько-політичному аспекті. Поширений погляд на революцію як подію в сучасній соціальній філософії. Таке тлумачення революції дають представники американської історичної соціології - Ф.Абрамс, М.Салінс, Э.Эбботт, Л.Гріффін. Звертають увагу на історичний розвиток і тлумачення 
поняття «революція» такі дослідники, як Г.А.Завалько, А.В.Магун, М.П.Одеський, Д.М.Фельдман. Наукові концепції революції розробляли Х.Аренд [1], Ю.Хабермас, Г.Маркузе. Цей напрям глибше розвивався такими сучасними дослідниками, як Т.Скочпол [10], Д.Голдстоун [4], Д. Мігдал та О.Павлов. Дослідники Л. Ісаєв, А.Шишкіна [5], О.Колобов та Е.Шульц особливе значення приділяють емпіричному матеріалу та конкретним революційним подіям XX століття та початку XXI ст. (постокумістичні, «кольорові» революції, «Арабська весна»). 3 вітчизняних дослідників - це О.Бобіна [2], А. Гальчинський [3], Ю. Мацієвський, М.Рябчук та А.Колодій.

На пострадянському просторі після подій 2004 року в Україні слово «революція» повернулось у мову політичної дискусії і соціальної думки. Але неначе розплатою за цю реабілітацію стала втрата змісту цього поняття. Замість обговорення суспільного перетворення почали міркувати про заміну міністрів, поділ влади і перерозподіл власності між правлячими фінансово-економічними угрупуваннями. Таке тлумачення концепту «революція» $є$ дуже зручним: 3 одного боку, воно дає можливість рішуче критикувати і викривати усі соціальні негаразди, а з іншого, - нічого не міняти - лишати все, як є. Воно, з одного боку, є визнанням реальності революції, а 3 іншого, - дискредитацією революції як такої. Так само зручною $\epsilon$ i назва «кольорові революції», за допомогою якої аналітики старанно стирають межі між масовими рухами низів і переворотами, влаштованими елітою у корисливих цілях, між соціальними перетворюваннями та інтригами у верхах, які призводять до перерозподілу сфер впливу між владними колами. Революцію часом тлумачать як змову i заколот зловмисників, які підривною агітацією підбурюють сотні, навіть мільйони людей вийти 3 протестом, піднятися на боротьбу, виступити на їх користь. Таке тлумачення виражає нездатність зрозуміти суспільні зміни, викликані масовими рухами, і прагнення звести будь-які суспільні перетворення до поділу влади, представити усі революції як варіації зіткнення панівних соціальних сил, їх суперництва у боротьбі за владарювання. У цьому ж виявляється страх перед масовими соціальними виступами, які лякають своєю силою i неконтрольованістю. Втім, рух історії свідчить, що саме такі виступи, перетворення масових рухів на силу, що творить історію, перекидає політичні режими, висуває власні вимоги, програми і вождів, відрізняють революційні епохи від інших часів. Отже, за умов сучасного перегляду змісту поняття «революція», його 
«революція», його модернізації і амбівалентного тлумачення наукове дослідження даного поняття на основі сучасних соціальних зрушень і процесів є, безумовно, актуальним.

Чим більше прагнуть ліберальні і консервативні критики редукувати будь-які суспільні зміни до поділу влади, чим наполегливіше доводять, ніби всі революції являють собою тільки варіації на тему «квіткової» або «кольорової» революції, тим більше виступає на перший план дійсна суть революції. Вона виражається положенням, згідно з яким початок революції незмінно провокується неможливістю відтворення певного суспільного ладу, його крахом, чим активізуються широкі маси, що залучаються до самостійного історичного виступу. Те, що називається кризою верхів, породжується не стільки бездарністю керівників, скільки неспроможністю економічних, соціальних і політичних інститутів, що вичерпали свій ресурс i потенціал існуючого суспільного устрою. Адже невдоволення i обурення, масова соціально-політична дія викликаються нездатністю можновладців вирішувати нагальні проблеми. Саме громадянська дія, вихід мас на передній план, їх консолідація, висунення власних вимог, програм, а також своїх лідерів відрізняє революційні часи від інших.

Є труднощі, з якими стикаються соціально-філософське дослідження революційних процесів, їх теоретична реконструкція і наукове передбачення і які можливо подолати лише на філософському рівні пізнання. Події такого історичного масштабу ніколи не відбуваються гладко, і якщо вони дійсно є кардинальними перетвореннями, то вони не можуть не зустрічати спротиву, і сам процес змін $\epsilon$ суперечливим і нелінійним. Також марно очікувати, що революція одразу і миттєво надасть готовий і завершений соціально-політичний, економічний, а тим більше культурний результат. Даремно також сподіватися, що революційний процес можливо зупинити в певному заздалегідь обраному пункті, бажаному для демократично налаштованого ідеолога або навіть більшості суспільства. Ліберальні прихильники свободи зазвичай стикаються 3 тим, що революція призводить замість обіцяного визволення до прямої протилежності - встановлення диктаторських режимів та вжиття всіляких авторитарних заходів, до війн. Водночас консервативні критики революції, навпаки, саме прагнення до свободи розглядають як причину всякого соціального лиха і дестабілізації, і тому відмовляються визнавати якусь різницю між буржуазними і пролетарськими революціями, 
між революцією і контрреволюцією. Наприклад, П.Сорокін вважав, що справа не у тому, як далеко заходять перетворення під час тієї чи іншої революції, а в тому, що будь-яке перетворення знизу, будьяка масова участь трудящих у суспільно-політичному житті є лихо, катастрофа і нещастя для країни, де таке сталося. Коли низи суспільства переймаються ідеями свободи і виходять з покори, тоді вони починають знищувати все підряд, економіка занепадає, країна переживає потрясіння і деградує, робітники стають ледарями, трутнями, паразитами. До якої б епохи ми не звернулись, яку б революцію не розглядали, «ми бачимо ті ж вимоги скорочення робочого дня, ті ж прагнення влаштуватися за державний рахунок, те ж зростання лінощів, витрату часу на мітинги, балаканину, пияцтво...» $[8,99]$. Таке зображення повалення панівного ладу бунтівниками виражає досить поширений погляд на революційний процес як на ланцюг соціально-політичних негараздів, що не мають об'єктивного змісту і каузальної зумовленості. Ця позиція щодо протікання процесу піддає осуду і самі змістовні зміни відносин, як дестабілізацію, руйнацію усталеного порядку, заміну його чимось непевним. Вона спирається на уявлення, що крах соціальної системи і катастрофічні соціальні потрясіння відбуваються через якісь дрібниці, частковості, випадкові помилки, не будь яких старий лад міг би ще існувати тривалий час. Саме тому спроби П.Сорокіна виявити закономірності, що призводять до революцій, скоріше нагадують скаргу: «Передреволюційні епохи просто вражають дослідника бездарністю влади і виродженням привілейовано-командних верств, нездатних успішно виконувати ні функції влади, ні протиставити силі силу, ні розділити і послабити опозицію, ні зменшити утиск, ні каналізувати його у формах, відмінних від революції» $[8,395]$. Втім, такий висновок робиться і стає переконливим лише заднім числом. До певного часу «адміністратори старого режиму» цілком успішно справляються зі своїми проблемами і сумлінно здійснюють саме те, що вважають за потрібне робити П.Сорокін та його прихильники, утримуючи у своїх руках владу і управління суспільством. Але лише до певного моменту, бо люди, структури, методи лишаються ті самі, проте раптом перестають спрацьовувати. Вони не вловлюють того, чого вимагають від них критична ситуація, суспільний конфлікт чи громадське протистояння, громадянська непокора, та не можуть адекватно відреагувати на обставини і події, що спричинює ескалацію і загострення конфліктних процесів. 
Здавалося б, арабські режими благополучно існували десятиліттями, не зазнаючи особливих труднощів управління своїми країнами, але у 2011 р. вони зазнали краху, як на перший погляд, раптово, наче виснажені. Органи влади, як і раніше, сумлінно намагались виконувати накази правителів, тільки замість звичних успіхів вони почали зазнавати однієї поразки за іншою. Правителі не втратили своїх владних інструментів, просто їх методи перестали працювати, даючи несподівані та навіть зворотні результати. Дорікання викликають і м'які дії влади (як у Тунісі, з боку консерваторів) i тверді (коли влада намагається жорстоко придушити виступи). В обох випадках боротьба не лише не припинялася, а й драматизувалася, набираючи форм, які завдавали представникам панівних режимів катастрофічних наслідків. Сильна влада, як і слабка, не може впоратися з новою ситуацією звичними, випробуваними у колишні часи засобами, інститути влади не відповідають поставленим на порядок денний економічним, соціально-політичним та ідеологічним завданням: вони нездатні відтворити колишній порядок.

Наприклад, у Лівії революційні події 2011 р. продемонстрували нездатність правлячих кіл керувати ситуацією. Вони не лише не контролювали процес, що відбувався у країні, а були нездатні адекватно реагувати на мінливі обставини і контролювати власні рішення, опиняючись заручниками попередніх зобов'язань, власної пропаганди, внутрішніх суперечок.

Активність мас, що бурхливо зростає за таких умов, теж не $\epsilon$ автоматично конструктивною і такою, що переростає у свідоме соціальне творення, історичну творчість. Масова соціально-політична дія також може давати результати, прямо протилежні заявленим намірам і вимогам, тобто деструктивні і несподівані для неї самої. Ця втрата спрямованості дії і неочікуваність результатів виникає через стихійність, неорганізованість, ідеологічну ангажованість тощо. I ця проблема теж заслуговує на уважне дослідження. Як констатував наприкінці 2011 р. Олександр Тарасов, «тахрір закінчився. А закінчився він переходом влади в руки військової хунти 3 подальшою перемогою ісламістів на виборах».

Отже, масовість антиурядових та інших протестних виступів, їх масштабність не $є$ гарантією їх позитивності та результативності. Так, стрімке зростання кількості учасників травневих демонстрацій 1968 р. у Франції не стало запорукою успіху цього протестного руху. За деякими даними $[7,96]$, кількість демонстрантів зросла з 10 тисяч 
6 травня до 800 тисяч 13 травня. Соціальна криза вилилася у десятимільйонний загальний страйк. Студентські маніфестації у США теж часом збирали сотні тисяч учасників, але це не дало грандіозних революційних результатів. Так, кількість демонстрантів у період антивоєнних рухів у США за три роки, з весни 1965 р. до весни 1968 р., зросла у 300 разів, кількість протестувальників, насамперед, студентської молоді, пішов на мільйони. Пік антивоєнного руху припав на травень 1970 р. - тоді виступили 350 університетів і коледжів [7, 74]. Проти студентів була направлена національна гвардія, протистояння досягло фази кровопролитних зіткнень. Але порівняно з очікуваннями, масовістю і активністю руху його результати не були настільки ж радикальними.

Кінець 1960-х років став переломним для усього світу. Невдоволеність станом справ вийшла назовні політичними кризами, що прокотилися по всьому світу - від Варшави до Ліми, від Берклі до Праги, від Парижа до Багдада. Деякі дослідники, наприклад I.Валлерстайн, назвали те, що відбулось, глобальною революцією. Втім, у 1968 р. вона завершилась суцільною поразкою. Якщо у Східній Свропі виступи були придушені силою, то в Америці та європейських країнах вони самі зайшли у безвихідь. До того ж саме у протестах 1968 р., на думку деяких політологів та істориків, слід шукати корені радикального зсуву вправо, котрий стався в наступні роки. «Протести молоді дестабілізували європейський і північноамериканський капіталізм, підірвавши систему компромісів, на якій була заснована післявоєнна західна демократія і соціальна держава» $[6,27]$. Наслідком цих потрясінь став висновок про «кризу демократії», «кризу регульованого капіталізму» і подальший правий поворот до неоліберального курсу. Зазначимо, що це зрушення було підготовлено багатьма факторами, серед яких найдієвішими були економічна криза і технологічна революція.

Але обернення революційного руху цього періоду на протилежні результати щодо бажаних має принциповий характер. Центр ваги критики у цих виступах змістився з капіталу на державу в іiі абстрактній формі. Увага акцентувалася на неприйнятті влади, сімейних і соціальних структур. Авторитаризм, репресивність, бюрократизм, корупція державної системи були головною мішенню протестів. Придушення особистої свободи, індивідуального вибору, творчої ініціативи та свободи самоорганізації уособлювалося в державі (інститутах, системі). Критичне ставлення до держави довго і старанно 
культивувалося і зіграло свою фатальну роль, коли ініціатива цієї критики перейшла в руки супротивника. Тому ці рухи були обеззброєні та виявились безпорадними, коли почався неоліберальний наступ на соціальну державу, адже вони власною діяльністю значною мірою підготували цю реакцію. Невипадково англійський політолог Адріан Пабст дійшов висновку, що результатом протестів 1968 р. стала політико-економічна перемога правих сил.

За визначенням О.В.Шубіна, «революція - це не лише те, що відповідає програмі того чи іншого революціонера. Соціальна революція - це така соціально-політична конфронтація, що розколює соціум, і спрямована на зміну фундаментальних принципів громадського устрою» $[9,132]$. Але вектори, в якому відбуваються ці зміни, можуть бути прямо протилежними.

Отже, вивчення історичного досвіду і уроків революцій другої половини XX - початку XXI століть сприяє усвідомленню, прогнозуванню подібних процесів, а також готовності до управління ними.

В періоди революційних потрясінь виникають такі стани, коли соціальний рух проти існуючих порядків стає надзвичайно пластичним, постає як відкрите перетворення і становлення, в якому уможливлюються взаємно протилежні напрямки розгортання змін. Невизначеність такого стану, по суті, є показником багатогранності тенденцій, яка неначе демонструє можливість соціальної форми стати будь-якою іншою і в якому завгодно напрямі реалізувати свої потенції. У такі періоди втрачається спрямованість процесів, розмивається межа прогресу і регресу. Внаслідок такої невизначеності та дезорганізації відбувається обернення протилежностей, і ця інверсійність не дає вийти за межі того суспільного устрою, який намагалися подолати, спроби соціального перетворення зводяться нанівець. Без наукового розуміння причин виникнення i свідомого запобігання таким наслідкам масові соціально-політичні рухи не мають шансів виконати роль суб'єктів історичного розвитку.

\section{ЛIТЕРАТУРА}

1. Арендт Х. О революции. - М., 2011. - 464 с.

2. Бобіна О. Про витоки теорії революції // Сучасна українська політика. 2008. - №13. - C. 88-93.

3. Гальчинський А. Помаранчева революція і нова влада. - К., 2005. - 367 с.

4. Голдстоун Д. К теории революции четвертого поколения // Логос. - 
2006. - №5(56). - C. 58-103.

5. Исаев Л.М., Шиикина А.Р. Египетская смута XXI века. - М., 2012. - 112 с.

6. Кагарлицкий Б.Ю. Неолиберализм и революция. - СПб., 2013. -256 с.

7. Мяло К.Г. Под знаменем бунта: Очерки по истории и психологии Молодежного протеста 1950-1970-х годов. - М., 1985. - 287 с.

8. Сорокин П.А. Социология революции. - М., 2005. -562 с.

9. Шубин А.В. Великая испанская революция. - М., 2012. -610 с.

10. Skocpol T. States and Social Revolutions: A Comparative Analysis of France, Russia and China. - Cambridge; N.Y. : Cambridge University Press, 1979. - P. 407.

Дерев'янко А.В. Інверсія прочесів, наслідків і усвідомлення револючії.

Темпи соціального розвитку на початку XXI ст. стали настільки стрімкими і драматичними, що гострі та невідкладні питання, поставлені його зламами і змінами, вимагають не лише науково обгрунтованих теоретичних відповідей, а й відповідних конкретних і вчасних політичних дій. Вивчення історичного досвіду і уроків революцій другої половини XX і початку XXI ст. дає можливість завчасно прогнозувати подібні процеси. В періоди революційних потрясінь виникають такі стани, коли соціальний рух внаслідок заперечення існуючих порядків стає надзвичайно пластичним. Без наукового розуміння причин виникнення і свідомого запобігання таким наслідкам масові соціально-політичні рухи не мають шансів виконати роль суб'єктів історичного розвитку.

Ключові слова: революція, соціальна революція, реакція, молодіжний рух, розвиток.

Деревянко А.В. Инверсия прочессов, последствий и осознание революиии.

В начале XXI ст. темпы социального развития стали настолько стремительными и драматическими, что острые и неотложные вопросы, поставленные его изломами и изменениями, требуют не только научно обоснованных теоретических ответов, но и соответствующих политических действий. Изучение исторического опыта и уроков революций второй половины XX и начала XXI ст. дает возможность заблаговременно прогнозировать подобные процессы. В периоды революционных потрясений возникают такие состояния, когда социальное движение вследствие отрицания существующих порядков становится чрезвычайно пластичным. Без научного исследования причин возникновения и сознательного предотвращения таких последствий массовые социально-политические движения не имеют шансов выполнить роль субъектов исторического развития.

Ключевые слова: революция, социальная революция, реакция, молодежное движение, развитие. 
Derevianko A. Inversion of revolution processes, aftermaths and realization.

In the second decade of XXI century the pace of social development accelerated so dramatically fast, all of urgent questions stated by its unexpected changes and breaks require not only nontrivial and scientifically justified ideological answers, but also corresponding and correctly measured and pertinent political actions. Socio-philosophical research of revolutionary processes faces certain complications as to their theoretical reconstruction and scientific prediction. Those complications can be overcome only on the philosophical cognitive level. The study of historical experience, lessons of revolutions and reactions during periods of second half of 20-th century-beginning of 21-st century gives an intellectual benefit of premature awareness, prognostication of those processes as well as readiness to control them. On conditions of reevaluating the meaning of «evolution» it's modernization and ambivalent interpretation, numerous explications and definitions, new theoretical conceptions and developments, scientific research, generalization and development of the notion's semantic substance based on modern social upheavals and processes is undoubtedly relevant. During the time of revolutionary upheavals a state might occur, when a social movement as a result of denying existing order becomes extremely flexible and stands as an open transformation and beginning, a flow that unites mutually exclusive directions of changes development. Without the scientific understanding of reasons for these aftermaths and consciously avoiding them mass socio-political movements have no chances to perform as subjects of historical development.

Key words: revolution, social revolution, reaction, youth movement, development. 